\title{
William Tolly and his Canal: Navigating Calcutta in the Late-Eighteenth Century
}

\section{Kaustubh Mani Sengupta}

Bankura University

\begin{abstract}
This article studies the making of one particular canal in the port-city of Calcutta during the early years of English East India Company rule in Bengal. Major Tolly, a Company-servant, proposed to undertake the arduous task of opening up a navigable route connecting Calcutta with the eastern districts of the province for better trade and communication facilities. In the process, he was hopeful of making a good fortune for himself as well. But the sailing was not smooth. Tolly had to enter into various negotiations with the Company government regarding land, the right to hold property in Calcutta, and the role of the Company in defining those rights. He also faced difficulties with the local zamindars regarding collection of tolls, and the issue of maintenance of the canal. The Company administrators were also not unanimous in their opinions regarding these issues, which sometimes compounded the problem for Tolly. Through a discussion of the material history of this canal, this article proposes to look at the ways in which a mercantile power sought to create and consolidate its hold over a coastal enclave in a largely riverine province, negotiating and redefining a maze of seemingly incomprehensible political-economic considerations.
\end{abstract}

\section{INTRODUCTION}

In 1775 Major William Tolly proposed to open a navigable canal connecting the river Hooghly in Calcutta and the Sundarbans, the marshy deltaic region stretching across the south-eastern part of the city, to facilitate trade and commerce. He intended to excavate a

(C) Kaustubh Mani Sengupta. This is an Open Access article distributed under the terms of the Creative Commons License CC BY NC SA, which permits users to share, use, and remix the material provided they give proper attribution, the use is non-commercial, and any remixes/transformations of the work are shared under the same license as the original. 
portion of the existing Surman's Nullah and extend it. ${ }^{1}$ At that point in time, boats could approach Calcutta only by a route close to the sea, which would bring them into the Hooghly by the Baratala Creek, situated seventy miles below Calcutta. This route was circuitous, and an impracticable one for the country boats during the monsoons. ${ }^{2}$ The English East India Company agreed to consider Tolly's proposal. The nullah [canal], which acquired its name after Tolly, soon became the major artery for goods coming from the rest of the province to the city. It was modified and extended several years later.

Canals were the cheapest thoroughfare for transporting materials to the colonial port city, and a system of canals connected Calcutta with other parts of the province. The Imperial Gazetteer of India (1909) described the 'Calcutta and Eastern Canals' as a:

System of navigable channels in the Twenty-four Parganas, Khulna, Backergunge, and Faridpur Districts of Bengal and Eastern Bengal, extending over a total length of 1,127 miles, of which about 47 miles, including Tolly's Nullah, are artificial canals, and the remainder are natural channels, mainly tidal creeks in the Sundarbans. These stretch eastwards from the Hooghly across the Ganges delta and afford means of intercommunication between the mouths of the latter river.... This is one of the most important systems of river canals in the world, judged by the volume of the traffic, which averages about 1,000,000 tons per annum, valued at nearly four millions sterling. ${ }^{3}$

Keeping in mind the importance of this navigation system in deltaic Calcutta, this article will analyse the early years of the enterprise, when Tolly entered into various negotiations with the Company government to sort out issues concerning landed property, the right to hold property in Calcutta, and the role of the Company in defining those rights. In the process Tolly also faced difficulties with local zamindars regarding collection of tolls and

\footnotetext{
${ }^{1}$ Tolly in his letter wrote: 'Hearing that it is the intention of the Honble [sic] the Governor General and Council to cut a navigable canal from Baliagaut [a landing place for goods coming from outside, situated two miles east of Calcutta] to communicate with the Nullah leading to Salmon's [Surman's] Bridge, and to conduct that to the river, I therefore humbly beg leave to offer my services for that purposes. The indulgence of directing that work upon the terms usually granted by the Company to the contractors for the excavations in the new Fort, might be a proper arrangement in the mode and manner of conducting it.' Home Department, Miscellaneous Branch, [hereafter: Home Misc.], Vol. 38 (10 July 1775), 80, National Archives of India, New Delhi, [NAI].

${ }^{2}$ Imperial Gazetteer of India, Provincial Series-Bengal, Vol.1 (Calcutta: Government of India, 1909), 242-3.

${ }^{3}$ Ibid., 242.
} 
the issue of maintenance of the canal. Tolly, and for that matter, the Company, were not entirely sure of the rights and privileges of the patta[lease]holders.

Through a discussion of the material history of an artificial canal, connecting the interior of a port-city to the wider deltaic network of channels, this article examines the ways through which a mercantile power sought to create and consolidate its hold over a largely riverine province. The customary claims made by the various zamindars on goods brought through the canal as well as on landing sites frustrated Tolly to no end. These claims cut into his profit margin and made the channel expensive for sellers. The competing demands of the landholders and Tolly complicated the matter for the Company. The Company government practically had very little options at their disposal to stop the landlords' collections. New rules and regulations were brought in the 1790 s to curb them.

I will discuss the stages of the canal project to understand the different ways through which Tolly and the Company negotiated the situation of land, tolls and taxes. These issues, I suggest, were linked to the wider concept of sovereignty. The Company acquired the revenues of the province of Bengal in 1765. Slowly, they eclipsed the nawab of Bengal to emerge as the de facto ruler of the province. In the process, the Company rulers were keen to establish their own regime of governance, which had to enter into various negotiations with existing norms and practices. The canal project needs to be read with this backdrop. It gives us an entry to the complicated world of land relations and customary practices that the Company had to negotiate in consolidating its hold over the port-city of Calcutta. So, before discussing Tolly's canal, first allow me to briefly chart out the historical backdrop of late eighteenth century Bengal, the nature of public works undertaken in the port-city, and how these infrastructures shaped the space of the town.

\section{Calcutta And the Company in Late Eighteenth-Century Bengal}

The political and economic power gained by the Company after the battle of Plassey (1757) and the right of diwani (collection of land revenue, 1765) directly influenced the development of the English settlement at Calcutta, while steadily marginalizing the nawabi towns and other European centres in the province. Through a series of treaties signed between English traders and Mughal rulers, the Company acquired a vast, prosperous tract in eastern India. In the southern part of the continent, the English company was locked in a bitter struggle with their French counterpart at this point of time. The military engagements in the south put a strain on the English coffers. The English did not face any such opposition in Bengal. In 1757, along with the events at Plassey, Clive 
destroyed the French settlement at Chandernagore and the nawabi outpost at Hughli. By this time the Danes and the Portuguese were also relegated to small pockets in Bengal. With their victory over the nawab, the English company practically scored over other European powers as well. The conquest at Plassey, as P. J. Marshall had put it, signalled a disruption in the Bengal polity where ' $[\mathrm{t}]$ he Nawabs were swept aside as Calcutta conquered Bengal. ${ }^{\prime 4}$ The piecemeal efforts of the previous decades suddenly seemed to be inadequate. But there was no grand sweep that could readily erase the past. The next few decades would prove to be crucial in the fortunes of Calcutta as, by the turn of the nineteenth century, it irrevocably became the most important urban centre not only in Bengal, but in the entire eastern part of the subcontinent. However, the period of this fortyodd years would also reveal the tensions, contradictions, and incompetency of merchants and mercenaries who were turned into administrators of an alien land and its people almost overnight.

In South Asian historiography, there is substantial discussion on urban centres and port cities in histories of overland and maritime trade networks. Cities and towns were important nodes in connecting the producer and intermediaries with the consumers of agricultural products. With the advent of European trading companies from the latefifteenth century onwards, port settlements of foreigners gradually emerged. The future metropolises of India had similar origins. Studying these settlements as part of trading histories, scholars have focussed on issues of circulation, social organization, relationships with the hinterland, and larger political networks. ${ }^{5}$ With consolidation of the colonial power by the turn of the nineteenth century, maritime cities started to change dramatically. The English settlements at Madras, Calcutta, and Bombay burgeoned. These centres maintained extensive connections with the interior for supply of exportable goods and merchandise. These linkages were crucial for the sustenance of the port-cities.

\footnotetext{
${ }^{4}$ P. J. Marshall, Bengal: The British bridgehead. Eastern India, 1748-1820. The New Cambridge History of India (Cambridge: Cambridge University Press, 1987), 92.

${ }^{5}$ As S. Arasaratnam mentions in the case of southern India: 'By investment and enterprise, by diplomacy and force, English interests and influence on the coast grew and their settlements became nodal points of Indo-British exchange and interaction. The timely demonstration of controlled power, both when faced with threats from the 'country' powers of the hinterland and from European rivals on the seafront, helped in the growth of these settlements beyond mere centres of trade. Providing, as they did, not merely trade and investment, but also security of person and property, they were naturally an attraction to many groups in Indian society in the hinterland.' See: S. Arasaratnam, "Trade and political dominion in South India, 1750-1790: Changing British-Indian relationships," Modern Asian Studies, 13, 1 (1979), 19. On complex trading interaction between the various denominations of 'town' and the 'country' in southern India, see: Sanjay Subrahmanyam, The Political Economy of Commerce. Southern India 1500-1650 (Cambridge: Cambridge University Press, 1990), esp. 2290. On port-cities in general, see: Indu Banga (ed.), Ports and their Hinterlands in India (1700-1950) (New Delhi: Manohar, 2019 [1992]); Frank Broeze, Gateways of Asia: Port cities of Asia in the $13^{\text {th }}$-20 $0^{\text {th }}$ Centuries (London, New York: Routledge, 1997).
} 
Discussing the early histories of these port-cities, Philip Stern has shown how the English East India Company acted as a sovereign power in these settlements, with their own fortification, currency, and legal system. ${ }^{6}$ More generally, Lauren Benton has analysed how the European mercantile companies created a system of enclaves and uneven territorial control in their overseas colonial possessions in the early modern world. ${ }^{7}$ However, in the case of Bengal, with the acquisition of the grant of diwani and de facto political power, the issue of sovereignty no longer remained confined within the zamindari of the Company at Calcutta and its neighbouring districts. The governance of Calcutta became connected with the larger geographical entity. The Company had to move into the interior of the province from their coastal base. Gradually, the administrative and economic power shifted to Calcutta. In 1772, Governor-General Warren Hastings moved the important offices of the province from the erstwhile capital, Murshidabad, to Calcutta.

These political manoeuvres were linked to the wider question of sovereignty. The Company's claim to sovereignty was a contentious issue - both from the point of view of the Bengal nawabs and also the Crown in Britain. ${ }^{8}$ The Company, by virtue of a series of charters and treaties, derived its authority from both the English and Mughal sovereigns. As Sudipta Sen mentions, during the Company's ascendancy in Bengal, Edmund Burke had identified 'the fundamentally dual source of the political authority of the Company.'9 The recognition of the Mughal system forced the Company throughout the latter half of the eighteenth century to negotiate with the existing pattern of governance-creating initially a system of indirect rule with the notion of 'dual government, ${ }^{10}$ searching for an 'ancient constitution' to follow, ${ }^{11}$ or reworking the land revenue system, often faltering in its execution and leading to disastrous consequences, as in the famine of 1769-70. These negotiations revealed the tension within the ranks of the Company officials as well as the

\footnotetext{
${ }^{6}$ Stern, The Company-state: Corporate sovereignty and the early modern foundations of the British Empire in India (New York: Oxford University Press, 2011).

${ }^{7}$ Benton argues that: 'Although empires did lay claim to vast stretches of territory, the nature of such claims was tempered by control that was exercised mainly over narrow bands, or corridors, and over enclaves and irregular zones around them' (Lauren Benton, A Search for Sovereignty: Law and geography in European Empires, 1400-1900 (Cambridge: Cambridge University Press, 2009), 2).

${ }^{8}$ Nicholas B. Dirks, The Scandal of Empire: India and the creation of Imperial Britain (Ranikhet: Permanent Black, 2008), 167-207; Sudipta Sen, Distant Sovereignty: National imperialism and the origins of British India (New York: Routledge, 2002); Sudipta Sen, "Unfinished conquest: Residual sovereignty and the legal foundations of the British Empire in India," Law, Culture and the Humanities, 9, 2 (2012), 227-242; Huw Bowen, "A question of Sovereignty? The Bengal land revenue issue, 1765-67,” The Journal of Imperial and Commonwealth History, 16, 2 (1988), 155-76.

${ }^{9}$ Sen, Distant Sovereignty, p. xv.

${ }^{10}$ For a contemporary account, see: Harry Verelst, A View of the Rise, Progress, and Present State of the English Government in Bengal (London: J. Nourse, 1772).

${ }^{11}$ Robert Travers, Ideology and Empire in Eighteenth Century India: The British in Bengal (Cambridge: Cambridge University Press, 2007).
} 
limits of the colonial transformations, which could not yet eliminate the competing claims of various zamindars and landholders. Tussles over land accumulation and property rights, rents from market places or revenue on commodities, regulation of labouring populations or managing sovereign claims over law and order, put the Company rulers in constant conflict with various social groups. ${ }^{12}$

Historians have long debated the nature and effects of changes wrought by the East India Company when it started to make inroads into the political arena of the subcontinent during the second half of the eighteenth century. ${ }^{13}$ Moving away from a scene of utter decline and all round ravages, as proposed by some nineteenth century leaders and writers as well as early nationalist historians, revisionist histories from the 1980s onwards have shown the continuing vitality of trade networks, establishment of towns and markets, and the prosperity of certain sections of traders and merchants. ${ }^{14}$ On the other hand, historians such as Kumkum Chatterjee and Sudipta Sen have indicated the slow transformations brought in by the new polity, which had wide-ranging effects on the social and mental world of the actors involved in the economic terrain. ${ }^{15}$ In recent years, the works of Robert Travers, Jon Wilson, and James Lees have brought forth an image of an uncertain and anxious Company-state in eighteenth-century Bengal, which moved ahead negotiating with an 'ancient constitution' of India or tried to fathom local property rights and structures of governance. ${ }^{16}$ While various negotiations and experiments were going on in the province at large, the situation at Calcutta altered rapidly during these decades. The English mercantile company succeeded in eclipsing the old capital and creating an administrative centre at the far south of the region, almost at the edge of the Bay of Bengal.

\footnotetext{
${ }^{12}$ For a critical analysis of the Company's claim to sovereignty with regard to property rights and right to sell land in an urban context, see: Bhavani Raman, "Sovereignty, property and land development: The East India Company in Madras," Journal of the Economic and Social History of the Orient, 61 (2018), 976-1004.

${ }^{13}$ See the major essays collected in the following volumes: Seema Alavi (ed.), The Eighteenth Century in India (New Delhi: Oxford university Press, 2002); P. J. Marshall (ed.), The Eighteenth-Century in Indian History: Evolution or revolution (New Delhi: Oxford University Press, 2003). For an early exploration of the problem, see: Eric Stokes, "The first century of British colonial rule in India: Social revolution or social stagnation?," Past and Present, 58, 1 (1973), 136-60.

${ }^{14}$ C. A. Bayly, Rulers, Townsmen and Bazaars: North Indian society in the age of British Expansion 1770-1870 (New Delhi: Oxford University Press, 2002 [1983]); Rajat Datta, Society, Economy and the Market: Commercialization in rural Bengal, c. 1760-1800 (New Delhi: Manohar, 2000); Tilottama Mukherjee, Political Culture and Economy in Eighteenthcentury Bengal: Networks of exchange, consumption and communication (New Delhi: Orient BlackSwan, 2013). ${ }^{15}$ Kumkum Chatterjee, Merchants, Politics and Society in Early Modern India. Bihar: 1733-1820 (Leiden: Brill, 1996); Sudipta Sen, Empire of Free Trade: East India Company and the making of the colonial marketplace (Philadelphia: University of Pennsylvania Press, 1998).

${ }^{16}$ Travers, Ideology and Empire; Jon E. Wilson, The Domination of Strangers: Modern governance in eastern India, 17801835 (London: Palgrave Macmillan, 2008); James Lees, Bureaucratic Culture in Early Colonial India: District officials, armed forces, and personal interest under the East India Company, 1760-1830 (London: Routledge, 2020).
} 


\section{Public Works in Early Calcutta}

With the coming of European trading companies, fortification became commonplace in coastal regions of the subcontinent. The urban settlement pattern started to change. Wellfortified structures, securing the white inhabitants and separating them from the indigenous population, became the main tenets of these cities. The issues of defence and the basic necessities of a public life (such as hospitals, churches, and gardens) prompted the companies to build some structures, but these did not follow any well-planned scheme. ${ }^{17}$ In terms of the material development of Calcutta, the Company embarked on the massive project of building the new Fort William in 1757, after the nawab's force destroyed parts of the older one. The amount of money spent on the structure was enormous, and the Company faced a series of problems regarding the organization of the necessary labour power and building materials throughout the two-decade period of construction. ${ }^{18}$

During the same period, various individuals put forth a series of proposals to undertake projects relating to public works. Company servants were keen to supplement their income with private trade or infrastructural projects. These opportunities were one of the major reasons for Europeans to venture out to the East. The Company did not mind these activities as long as they did not compete with the Company's monopoly over piece goods, salt, salt petre and opium. ${ }^{19}$ Debjani Bhattacharyya has recently discussed one such project in her book, Empire and Ecology in the Bengal Delta. Benjamin Lacam, a company-servant, wanted to build a wet-dock in deltaic Bengal. The Company granted him the necessary permissions, but in the end the project failed due to various ecological and economic factors. ${ }^{20}$ Even when they did not succeed, these private speculative ventures give us an indication of the ways through which the early Company-state tried to manage, develop and shape the fluid landscapes of Calcutta and its hinterland.

Bengal, with its extensive river-networks, always had waterways as a major route of communication among different towns, villages, producing centres, and

\footnotetext{
${ }^{17}$ Partha Mitter, "The early British port cities of India: Their planning and architecture circa 1640-1757," Journal of the Society of Architectural Historians, 45, 2 (1986), 95-114.

${ }^{18}$ Kaustubh Mani Sengupta, "The New Fort William and the dockyard: Constructing Company's Calcutta in the late eighteenth century," Studies in History, 32, 2 (2016), 231-56.

${ }^{19}$ P. J. Marshall, "Private British investment in eighteenth-century Bengal," Bengal Past and Present, 86 (1967): 52-67, reprinted in: P.J. Marshall, Trade and Conquest: Studies on the rise of British dominance in India (Aldershot: VARIORUM, Ashgate Publishing Limited, 1993).

${ }^{20}$ Debjani Bhattacharyya, Empire and Ecology in the Bengal Delta: The making of Calcutta (Cambridge: Cambridge University Press, 2018), 45-76.
} 
marketplaces. ${ }^{21}$ The Company needed cheap options to bring in commodities to Calcutta, and the use of the waterways was extremely important in that regard. The project of the canal was thus crucial for the Company as well. Historians such as Ravi Ahuja and Nitin Sinha have shown the importance of communications in terms of transport system for the early colonial state. ${ }^{22}$ For military and commercial needs, the Company government wanted to control routes of communications, such as roads, waterways, and later, railways. And in these efforts, Company men produced the social space of the colony that tried to erase precolonial spatial practices and create new meanings of the landscape. Nitin Sinha has argued that the processes of objectification of spaces sought for by the colonial rulers in India through 'inferiorizing and negativizing' the customs and landscapes of the natives 'were not always absolute: they were relative and relational. This would mean that even under colonialism, at one point of time the given impulse to objectify spaces and practices could not only be driven by divergent needs of the rule but that some of those impulses and needs ran contrary to each other. ${ }^{23}$

I engage with these formulations in studying the making of the canal in early colonial Calcutta. I show the ways through which new forms of power relations put their imprint on the morphology of the town, generating out of conflicting interests and various negotiations. As Henri Lefebvre has argued, there is a 'historicity' of social space; it contains traces of the past. No one group can dominate the space, or eradicate the presence of other groups who are at variance. Lefebvre writes, 'In space, what came earlier continues to underpin what follows. The preconditions of social space have their own particular way of enduring and remaining actual within that space. ${ }^{24}$ Humans appropriate natural space to build new spatial elements such as roads and canals, villages, towns, and markets. Following Lefebvre, Ravi Ahuja tells us, 'These spatial elements are not simply 'things' - they are at once locatable objects and spatial relations. Social spaces are constituted through a complex of such relations - spatial relations that are inseparably integrated with relations between social groups, with property relations in general and

\footnotetext{
${ }^{21}$ Radhakamal Mukherjee, The Changing Face of Bengal: A study in riverine economy (Calcutta: University of Calcutta, 2009 [1938]); Mukherjee, Political Culture and Economy, 147-58.

${ }^{22}$ Ravi Ahuja, Pathways of Empire: Circulation, 'Public Works' and Social Space in Colonial Orissa (c. 1789-1914) (Hyderabad: Orient BlackSwan, 2009); Nitin Sinha, Communication and Colonialism in Eastern India: Bihar, 1760s-1880s (London, New York: Anthem Press, 2012).

${ }^{23}$ Sinha, Communication and Colonialism, 22.

${ }^{24}$ Henri Lefebvre, The Production of Space (Oxford: Blackwell, 1991), 228; Also, elsewhere he mentions: 'The past leaves its traces; time has its own script. Yet this space is always, now and formerly, a present space, given as an immediate whole, complete with its associations and connections in their actuality. Thus production process and product present themselves as two inseparable aspects, not as two separable ideas.' (Ibid., 37).
} 
relations of land control in particular. ${ }^{, 25}$ Focusing on this notion of appropriation of natural space, I look at the materiality of the waterway to understand the relations between the Company-state, individual entrepreneur, and the society, and how they shaped the development of the settlement in its early days. With this general backdrop in mind, let us now look closely at the project of the canal.

\section{Company And Tolly: Terms of The Grant}

Before Tolly, Henry Watson was interested in excavating the canal. Watson at that time was already engaged in the construction of a dockyard at Kidderpore, a spot on the river Hooghly in southern outskirts of Calcutta. In a letter to the Directors of the Company, he wrote extensively on the advantages of opening up a navigable canal. He mentioned that the canal would facilitate export trade with the manufacturing provinces of Chittagong and Dacca in eastern Bengal, as well as inland trade in Calcutta, and also improve the condition of the waste-lands in the Sunderbans, located to the south of the city. Watson also highlighted that such a canal would help in having a back-water, and would ease up the entrance to the dock under construction. ${ }^{26}$ In the end, though, Watson did not get the nod from the Company regarding the channel. The reasons for Company's favouring Tolly over Watson is not clear from the records. Perhaps, the terms proposed by Watson were not agreeable to the Company, or maybe, the Company did not want to put all its eggs in the same basket.

Once Tolly received the approval from the Company, he chalked out the details of the project and presented it to the Board of Revenue. He proposed to start the work partly on his own expense, but also wanted the Company to pay an advance of eighty thousand rupees and a grant of tolls on all boats for two years. In his next letter to the Board, however, Tolly proposed new terms for the work:

I will undertake the Completion of this navigation exempt of any Expense to the Company and... finish the same in three years in consideration of a Grant of a Toll, of One Per Cent on the Aurung invoices of all Goods brought by that Navigation. The said grant [is] to be for 12 years from the Commencement of the Works. As the navigation will not be open for Boats

\footnotetext{
${ }^{25}$ Ahuja, Pathways of Empire, 25.

${ }^{26}$ Auditor's Reference 1773 to 1782, Vol. 3, India Office Records (hereafter: IOR) D/149, 28-31, British Library (hereafter: BL), London.
} 
in less than three years, no Duty of course will arise and a heavy Expence [sic] during that Time will attend the Work-for these Reasons it is humbly requested - that the Honble the Governor General and Council will be pleased to extend the Grant to that Period of Time. ${ }^{27}$

Tolly intended to impose a toll on the goods brought through the canal for twelve years as part of his contract. In terms of the route after a survey, he proposed two lines in which the canal could be opened up. One option would connect through northward of Calcutta, and the other in a southward direction. The southern line seemed to be an easier option, as it interfered with few habitations. He wrote:

The quantity of ground in the southerly line that will be required will be about four hundred Begas, including the banking of the same. The far greater part of which is paddy fields and waste ground. The Line does not interfere with any houses until it comes to Chuckerbere, and Bhowanypore, the greater number of which are small mat houses - though it might be carried by the way of Callygaut, and not therein have the advantage of not interfering with private property. ${ }^{28}$

He also submitted the "names of the proprietors in the Southerly line, with the portion of ground belonging to each that will be effected by the channel, and the proportional annual rent paid to the company. ${ }^{29}$ With regards to the northern line, Tolly mentioned that the ground was high and more valuable. Consequently, it would require more money to purchase. Also, costs would be driven up because of the need to build bridges in many places. He concluded:

Upon a rough estimate, the expense of the execution will be nearly double to what it would be in the first intended Line. But as this direction has superior advantages to the public, I humbly beg to offer it to the consideration of the Hon'ble Board. ${ }^{30}$

\footnotetext{
${ }^{27}$ Home Misc, Vol. 38 (11 Sep. 1775), 127, NAI.

${ }^{28}$ Home Misc, Vol. 38 (28 Dec. 1775), 247, NAI.

${ }^{29}$ Ibid., 248.

${ }^{30}$ Ibid.
} 
However, should 'the private property in this line render it not practicable,' he wrote that the southern line would be much better to follow than looking for any other options in the northern section of the town. In the end, the Board opted for the southerly line proposed by Tolly. They agreed to authorize him to execute the project on his own expense. ${ }^{31} \mathrm{~A}$ grant was made for twelve years with authority to collect tolls of one per cent on the price of all goods transported via his canal. The Board also assured him of assistance in settling with the ryots (cultivators) living in and adjoining the course of the canal. ${ }^{32}$

The most contentious aspect of the agreement pertained to the ownership of land required to build the canal. Tolly was not granted land as and when or where he wanted. The Company did not give him any property rights on the land 'which may remain on either side of the banks of the Canal, excepting the right of tracking Boats on One side.' He was also 'not allowed to have any property in any of the Lakes, nor Nullas, which may run into his Canal, nor in any ground which is not... specifically granted to him. ${ }^{33} \mathrm{He}$ was allotted 2000 bighas of waste land, which was not someone's private property at the place where the canal would meet the Baliagaut or salt water lakes. Tolly was free 'to widen or improve the Navigation of any Nullas, leading into or thro' the Baliagaut lake, as he shall find expedient or convenient,' but was not given permission to establish chokeys to collect duties on those channels. 'His right in this respect [was to] be confined to the Limits of his own Canal, included between the River Houghly, and its Junction with the Baliagaut lake. ${ }^{34}$ The Company also made it clear that it would not demand any rent from Tolly for the grounds granted to him; however, all the lands and right to collect duties from the canal should revert back to the Company after a period of twelve years. The Company assured him that if any other canal needed to be excavated within this period, Tolly would get the preference. But the government reserved the right of building any necessary bridges over his canal, and Tolly would not have any right to collect tolls from the passengers using any bridge over his canal. ${ }^{35}$

Within a year, Tolly realized that he might not get enough returns on his investment under the existing terms of the agreement with the Company. At the outset he mentioned in his letter to the Company that, 'I have served the Company between thirteen and

\footnotetext{
${ }^{31}$ Ibid., 254.

${ }^{32}$ Proceedings, Calcutta Committee of Revenue [henceforth, CCR], OC, 10 Oct 1776, No. 6/7, West Bengal State Archives [WBSA], Kolkata.

${ }^{33}$ Home Misc, Vol. 40 (16 Jan. 1777), 60, NAI.

${ }^{34}$ Ibid., 60-1.

${ }^{35}$ Ibid., 61.
} 
fourteen years, and in the course of which time I have not improved my fortune. ${ }^{36} \mathrm{He}$ was quite certain that it would be impossible for him to accrue advantages from the project after paying off his debts. He proposed to alter the original course of the canal. The new direction to be followed was seven miles longer than the previous one, and he proposed to connect the canal with an existing channel. He asserted that the new direction would be beneficial to the Company and would make communication with the eastern part of the province easier than before. But there were some difficulties. He wrote,

In that operation is much Labour, expence [sic], and uncertainty of its not being a continual one. Strongly embanking each side of the Channel will be attended with an immense charge and trouble, and yet it is not clear to me, but that, that method, will in the end, be indispensable. The people employed on that work, will not only be in water during the time, but they will also be deep in mud, as every part to the eastward will reap a particular benefit from this New intended Channel in the Lake, by having an opportunity of importing goods at any season of the year, a circumstance that never attended them before, they certainly therefore never could be averse to the reimbursement of an individual, who had undertaken this arduous task, risk, and hazard, and thereby rendered them that Convenience. ${ }^{37}$

Tolly also proposed some new measures and terms of the lease, which would help him in the long run. He was keen that the Company would appropriate the land on both sides of the canal so that he could strengthen the banks as well as create places for the merchants to land their goods. This, according to him, would serve 'a double advantage...to the Company' as they would not only be able to collect the duties, but also secure profits from the higher land values. ${ }^{38}$ Further on, he mentioned that since the Company had little ground on the banks of the canal, some sort of arrangement with the ryots was necessary. He presumed that this would be an expensive affair; but on the other hand, the banks were needed to be secured, as with the improved state of the ground after the canal was opened and a regular route became operational, the Company might find it difficult to settle with the ryots even at the present rate. Tolly offered a solution to this issue. He urged that to avoid these difficulties, the Board of Revenue could permit him to become the tenant of

\footnotetext{
${ }^{36}$ Home Public (21 Apr. 1777), NAI.

${ }^{37}$ Ibid.

${ }^{38}$ Ibid.
} 
the Company for those lands, and allow him 'to pay the Revenue... and letting them [ryots] remain in their possessions. By this method, the Reiats [ryots] might be under some management, and thereby be the means of securing me from the Danger, to which I otherwise must inevitably be subject. ${ }^{39}$ But this arrangement would effectively bring those lands under his possession and make the ryots his tenants instead of the Company. This was again a contentious matter, since in effect the arrangement would transfer the proprietary rights from the Company, an issue which would be pointed out in the discussion of the Board members.

Apart from the question of land, the other concern raised by Tolly was regarding the collection of duties. This was another major source of revenue, which the Company initially denied him to collect from his canal. Since the channel was narrow, Tolly contended that it needed to be widened so that larger boats approaching from Dacca, Luckipore or Chittagong could come through that channel and then through his canal directly to the city. However, as this was an expensive and labour-intensive proposition, Tolly wanted to establish a chokey [collection centre] at the mouth of the channel to collect tolls from the boats coming up that way. This collection-point would be in addition to the tolls he was supposed to collect on goods passing through his canal. He reasoned, 'As these are thoughts that have not been suggested by any other person, and undertaken independent of any risk to the Company, I therefore entertain the most flattering idea that the Hon'ble Board will guard me against the probability of suffering a capital loss.... ${ }^{, 40}$ So, in the end, Tolly's various demands to the Board were as following:

a) To favour him with a grant in perpetuity, as the work was conceived and executed by him solely, with his own expense, and as it was a work which would benefit the public and also an advantage to the Company who did not have to bother about its maintenance if it were to be granted to Tolly.

b) To permit him to establish two chokeys to collect tolls from the widened canal.

c) To grant him with one thousand bighas of waste land, adjoining the old canal, as well as at the mouth of the canal, both to be made rent free.

\footnotetext{
39 Ibid.
}

${ }^{40}$ Ibid. 
d) To be permitted to have markets, to receive grain and merchandize, at the mouth of the canal adjoining the Hoogly [sic] river, one near the middle of the canal, another near the lake [at the end of the canal], and another on the waste land, adjoining the old canal.

e) To be allowed to take possession of all the ground that he could clear and which were not yielding any profit to the Farmer or Company at present.

f) To bestow him with the sole privilege of cutting any new canal. The Company was free to erect bridges near the canal, but he insisted that no toll should be collected on any bridges built by him.

The Board considered Tolly's various proposals. The members offered divergent point of views regarding his plan. While initially Governor-General Warren Hastings agreed to grant Tolly the right to the canal in perpetuity (which seemed to be his most important demand), other members rejected this right away. Hastings' arch-rival, Philip Francis stated that, 'I never heard a Toll or Duty being granted in perpetuity to an Individual. Any grant of this nature is in itself an alienation of the Rights of Government, which the public service may make it hereafter necessary to be resumed. ${ }^{41}$ General Clavering was more scathing in his assessment of Tolly's requests. He mentioned that:

Major Tolly must certainly have the worst opinion of our understandings or our honesty, to suppose we will change a Twelve years lease into a Grant of a perpetuity without our receiving every Compensation in Exchange, indeed when the advantages that are to accrue to the Company at the Expiration of the Term are considered I believe it will be found that no Compensation adequate to the disadvantage which the Company and the Country must suffer can be given were those advantages relinquished by the extension of the Term to a Perpetuity. ${ }^{42}$

Clavering stated that when the original terms were laid down, it was clearly stated that Tolly would be indemnified by a toll, the rate of which was left to him to fix. It was also assumed that Tolly would fix the rate in such a way so that it would not exceed the expense of bringing in merchandise to Calcutta in a more circuitous way or by land carriage.

${ }^{41}$ Ibid.

${ }^{42}$ Ibid. 
Clavering argued that, 'It was obvious however that the Proprietor would make his Calculations so nicely that the benefit to the Country was only to be expected at the Expiration of the term when the navigation might be laid open. ${ }^{43}$ Thus, he found no reason whatsoever to grant any of the new demands made by Tolly, and as far as the altered circumstances that compelled him to take a different route were concerned, Clavering thought that they were 'too frivolous to have any weight,' as Tolly should have carefully done his initial survey and then made the calculations. Apart from the tenure of the lease, Clavering also rejected the plea to hold any extra land. He found no connection between the grant of the canal and holding any waste land, falling outside the limit of the town of Calcutta, in perpetuity. He argued,

That the Court of Directors have forbidden Europeans to hold Land in the Province, and will now further add that even had they been silent on the subject, I should not deem the Governor General and Council competent to grant the Lands of Bengal in perpetuity, the act of Parliament only empower them to order, manage and govern the Lands, but not to give them away and as Representatives of the Company in their Character of Dewan I think we are still less entitled to do it. The lands are either the Zimindars or the Nabobs...44

He said that some limitations should be put on the power of the council to distribute land outside the limits of Calcutta and its districts either in perpetuity or in a lease, and if such grants were to be made, they should not be considered as valid until approved by the Court of Directors. In the matter with Tolly, in the end, the Board resolved to grant him some space to establish a market:

Ground comprehended between four equal lines, from Major Watson's wall along the banks of the River towards the Fort extending to the distance of twenty feet on the north side of the mouth of his Canal which opens into the River for the purpose of establishing a gunge on condition that he will neither erect nor suffer to erect any buildings of masonry or mud upon it, and that he be not allowed a gunge at another place. ${ }^{45}$

\footnotetext{
${ }^{43}$ Ibid.

${ }^{44}$ Ibid.

${ }^{45}$ Home Public (21 Apr. 1777), NAI.
} 
Tolly was not granted any pottah (lease) for the land he requested on either side of the canal. He was also not allowed to erect any additional chokey on erstwhile channels running into his canal to collect tolls. And, finally, the question of granting him the canal in perpetuity was rejected by the Board at Calcutta, though Hastings maintained that the demand would be forwarded to the Court of Directors for their comments.

The fact that Tolly was not allowed to establish a chokey (apart from collecting tolls from his own canal) is not surprising. The Company in this period was trying to streamline collections from trade routes and markets. The idea was to abolish all dues and tolls collected by zamindars and landlords over roads and canals and from the marketplaces. This was sair (duties). It was a tax on goods and things on the move. Looking at the usage during the Mughal period, Sudipta Sen notes that:

The term sair...is derived from the Arabic root meaning a traveller, passerby, or wanderer. Jihat...in the Safavid usage meant duties on manufactures. Together, in the Mughal convention, sair-o-jihat...distinguished normatively from revenue arising from the cultivation of land ( $\mathrm{mal}$ ), marked all other sources of wealth, particularly proceeds from trade and marketplaces. ${ }^{46}$

Sair was also seen as the 'remainder,' an excess of the land revenue. ${ }^{47}$ The Company government wanted to abolish these privileges of the zamindars and establish a new system, distinct from the prevalent Mughal practice. It hoped to be the sole claimant of the tolls, with the landlords having the rent for the ground on which the bazaar was held. ${ }^{48}$ This was in line with its notion of indivisible sovereign power. But, as we will see in the next section, people constantly claimed traditional rights and privileges, frustrating the Company's attempt at establishing its authority. In the present case, thus, the Company had to deal with two sets of claims - one by Tolly, and the other by the landholders adjoining the route of the canal.

\footnotetext{
${ }^{46}$ Sen, Empire of Free Trade, 22.

${ }^{47}$ Anandaroop Sen, "Early years of East India Company rule in Chittagong: Violence, waste and settlement, c. 1760-1790," Indian Economic and Social History Review, 55, 2 (2018), 147-81.

${ }^{48}$ Sudipta Sen has persuasively argued that along with the land revenue settlement of the 1790s, the Company also tried to get a firm hold over the market-places and fairs. He sees the abolition of the sair duties or the settlement of the markets in the 1790s as the 'other prong of the permanent settlement of revenue.' See: Sen, Empire of Free Trade, 134.
} 


\section{Right to Collect Tolls}

In 1779 , when the canal was already in use, Tolly complained that people were taking advantage of the canal illegally, and that the Board must stop that. He alleged that Manick Doss, the farmer [lease holder] of a part of land through which the canal flowed, was levying a tax on the boats of fish brought by the canal. Also, he was holding a chokey on the road to collect duties on fish brought through the canal. That it was customary 'to levy a small Duty on Fish found in morass Ground in the Mugrah and Balliah Pergunnahs, and brought by People in Baskets on their Heads by the Russapuglah Road' was a well-known fact, but Tolly pointed out that salt water fish from remote places like Kalna and Jessore [lying in the eastern part of the province] did not come to Calcutta before he opened up the canal. ${ }^{49}$ He alleged that Manick's claim on fish coming through the canal discouraged fishermen from it. In his defence, Manick admitted that he collected some nominal amount on the fish, but he never stopped any boat on the canal, and claimed that it was an established custom to collect duties at chokeys on the banks of the river. The Sheristadar (administrative officer of the court) confirmed the prevalence of this practice. The Sheristadar mentioned that Manick collected tolls at two chokeys, one on the bank of the canal at Bavannypore and one on the road at Belletullah: 'In the former Duties are collected on Boats containing Wood and Fish by Computation. At Belletullah, on fish only. ${ }^{50} \mathrm{He}$ also informed the government that these chokeys were old establishments. Manick said that when the area was farmed out to him (in $1185 \mathrm{BS}$ or 1777/78 CE), the sair of Belletullah (which was a chokey on the road) was included in the farm, and he collected taxes from persons using the road to bring fish from distant parts like Jessore. This was according to an established custom, and he asserted, 'I collect nothing unauthorised.' 51

These addresses were made to the president of the Calcutta Committee of Revenue. The Committee observed that customs and taxes had already been abolished by a Public Regulation of the President and Council issued through the Board of Customs on 14 April $1773 .^{52}$ But, still, the Committee did not think it prudent to punish the farmer or ask him to stop collecting the tolls, as that might pose another problem for the government. The abolition of the taxes might become a pretext for the farmer to appeal for a deduction in his rent, and the Council was not keen on any kind of reduction, even if at times that meant

\footnotetext{
${ }^{49}$ CCR (16 July 1779), 183, WBSA.

${ }^{50}$ Ibid., 186-87.

${ }^{51}$ Ibid., 189.

${ }^{52}$ CCR, Letter from CCR to Governor General and Council (4 Aug. 1779), 23, WBSA.
} 
going against their own regulations. The members of the Revenue Committee were also not sure if the taxes were abolished everywhere, as they found from the accounts that the two chokeys were part of the sair farmed by Manick Doss and the amount collected there in 1185 BS (after the opening of the canal) was Rs $2466.10 .10 .^{53}$ The members of the Committee decided not to abolish the collections and duties as complained about by Tolly. They referred the matter to the higher authority, the Council at Fort William. ${ }^{54}$ Needless to say, Tolly was not pleased with this decision. To him, the matter was pretty simpleManick was collecting unauthorised tax, which in turn was hampering his prospects. He did not hide his displeasure while writing to the Committee:

A Person addresses a Proposition to the members of Administration, that he will open, at his own Risqué \& Expense, a Water Communication with the Eastern Provinces, Salt Water Lakes, Sunderbuns, and the Houghly River, by which means there will be an Importation of ten thousand Fish from those Salt Rivers - this will employ more People, the industries will become easy, and the Increase of a number of Fish will decrease the Price, and the Public will receive benefit - Government adopts this Proposition. The Work is executed. The Farmer unauthorised \& without any additional Power forcibly seizes the advantage that has been gained by this Expence [sic] of money \& Labour, although he has been no-wise [no way?] instrumental in effecting it. ${ }^{55}$

He argued that heavy taxation would hinder people from using the canal more frequently, and that the government should try to abolish the toll collected. He reminded them that 'Indulgences from Government are extended to public works in Europe. ${ }^{56}$ In England, the regulations were that tolls collected for repairing roads [Tolly considering the canal as a road or passage] were not to be rated, and 'the Persons employed in collecting such Tolls and repairing such Roads, shall not be liable to the Tax, by Reason of their said

\footnotetext{
${ }^{53}$ CCR, Duan's Report (4 Aug. 1779), 20, WBSA.

${ }^{54}$ CCR (16 July 1779), 190-1, WBSA. Also: "We are of Opinion that the Continuance of these Chokies is contrary to the above Orders of the Board of Customs, as well as to the Purport and Spirit of the Grant made to Major Tolly...But as a Claim to a Deduction from the Publick [sic] Revenues would follow the abolition of them, we do not think ourselves authorised to do it.' CCR (4 Aug. 1779), 23, WBSA.

${ }^{55}$ CCR (4 Aug. 1779), 16-17, WBSA.

${ }^{56}$ CCR (4 Aug. 1779), 18, WBSA.
} 
employment. ${ }^{57}$ Tolly hoped that the same assurances would be forwarded to him as well, as the canal was 'the first work of the kind undertaken in this Country.' He reasoned:

Taxations properly levied have salutary Effects, but urged beyond certain Limits, becomes, not only of prejudicial Consequence to the Public...but finally it will be levying a Tax on the Profits of the Canal which it cannot bear, and, instead of promoting the use of it, will be unfrequented and consequently in Reality a Tax on me. ${ }^{58}$

The Council at Fort William deliberated on the matter and finally resolved that all duties collected at chokeys on articles brought through the canal must be abolished as it was inconsistent with the terms of the grant to Tolly.

Though the government and Tolly were concerned with the loss this entailed for either of them, the clash between Tolly and Manick was part of a wider realm of political economy. Different notions of the waterways were at work here. The Company and Tolly were clearly trying to open up a space of unhindered movement for goods, with one-time payment of tax to the proprietor. However, collecting tolls on the passage was a practice well-established throughout the province. As Sudipta Sen mentions:

The Zamindar's privileges and rights over passage of boats, pilgrims, and merchandise - the accumulated hieroglyph of customary rule... stood directly against the jurisdiction of the Company. Such rights were the first to be threatened with the coming of British rule in this part of India. ${ }^{59}$

In the following years, the Company would establish custom-houses at select points to collect taxes on merchandise. It asserted its claim over the goods-on-move by simultaneously establishing the customs department and declaring all other claims over them as illegal. The crucial point to note here is that the 'customs houses were erected on the very places where the former Nawabs or Zamindars had claimed their traditional dues,' and thus 'the Company was not only expanding its revenue base but usurping memorable locations in the whole terrain of commerce and politics. ${ }^{60}$ Tolly's case gives

\footnotetext{
57 Ibid., 18.

58 Ibid.

${ }^{59}$ Sen, Empire of Free Trade, 97.

${ }^{60}$ Ibid. 99-100.
} 
us an early indication of the system to be pursued in future. The evolving pattern of governance of the trading Company can be discerned here. As the Company was much more certain of its hold over the port city than the interior, it could impose a strict order of suspension of customary privileges in Calcutta during these early decades of its rule.

\section{The Company Takes the Canal}

According to the terms of the lease, the Company was supposed to acquire the canal twelve years after its initiation. Meanwhile William Tolly had died, and his wife had inherited the right of the lease. In 1785, she requested the Company to extend the lease of the canal for another fifteen years, as the initial expenditure to open the canal far exceeded the original budget. Her request was granted by the Company, and the right to the canal was extended. However, soon certain legal problems arose. According to the terms of the lease, the government was not allowed to open any other canal in the vicinity of Tolly's Canal. Also, it was reported that some of the bridges on the canal and the general state of navigation were not in a proper condition. The government thought that it would be beneficial for trade and commerce if it could buy back Tolly's Canal by paying proper compensation to Mrs. Tolly. She agreed to the idea and put forward through her attorney, the amount the Company should pay her as compensation. Taking into account the amount of rent payable to the Company as per the lease and the number of years left for the expiration of the same, and speculating an estimated profit that Mrs Tolly could make, the attorney arrived at an amount of Rs 6,13,008. ${ }^{61}$

The members of the Board found the sum to be too high. The Governor-General observed that although the general public would be greatly benefitted if the canal was under Company's authority, the terms offered by Mrs. Tolly exceeded:

All reasonable compensation for the surrender of the grant, that to make the benefit to the publick [sic] what it ought to be, the Tolls and Duties now levied, upon Boats and merchandize passing through this channel, must be in a great measure abolished, and thus the pecuniary value of the grant to the Company would be very much diminished. ${ }^{62}$

\footnotetext{
${ }^{61}$ Letter from William Jackson, Attorney of Mrs Tolly, Extract Bengal Public Consultation, 11 Sep, 1795, Board's Collection, F/4/19, 770, Vol. 19, 1797-98 (13 Aug. 1795), Oriental and India Office Collection (hereafter: OIOC), BL. ${ }^{62}$ Ibid.
} 
Also, it was noticed that under the terms of the lease, Mrs. Tolly was supposed to take care of the bridges. The Board found that one of the bridges was in need of immediate repair, and the others would probably need rebuilding soon. These expenditures were not taken into account by the attorney while calculating the compensation. So, the Company declined the offer. It asked the attorney to provide a detailed account of the collections of the previous months. He did so for the past 39 months. The average calculated was Rs 4371, 'after deducting all expenses of collections,' but he also reminded the government that the amount would have been much greater (an additional sum of three hundred rupees per month) if the duties on markets abolished by government orders were taken into account. The tolls from the canal also suffered some losses due to new channels of communication, which, the attorney reminded, should not have been opened as it was against the terms of the agreement with Tolly. $\mathrm{He}$ mentioned:

A considerable loss is reported to me to have been occasioned also by a cut or canal made by or under the directions of the salt agent at Barrapore through which instead of coming through the nullah as formerly, the salt and other articles of merchandize of that district are conveyed to Calcutta. ${ }^{63}$

He then gave a detailed list of the various tolls collected at different points of the canal and of the rates of collection at each station. However, the Board pointed out that the accounts provided by Mrs. Tolly and her attorney did not take into account the amount needed to repair the bridges and the periodic clearing of the canal to keep it in a navigable state. These expenditures should be deducted from the amount collected as tolls to have the actual income from the canal, insisted the members of the Board. The amount put into repair was provided by the attorney, and the government taking into account all the possible income and expenditure associated with the canal arrived at the figure of Rs $5,72,803$ (including repair and building a new bridge) as compensation to Mrs. Tolly. This amount was gladly accepted by Mrs. Tolly and her attorney. ${ }^{64}$

However, the story did not end here. The government thought that it was necessary to have a final survey of the existing state of the canal before finalizing the deal. And this survey by R.H. Colebrook, the Surveyor-General, completely washed out all chances of the canal being bought by the government. Colebrook described the canal in the following terms:

${ }^{63}$ Ibid.

${ }^{64}$ Ibid., Letter from Mr Johnson, Consultations (5 Apr. 1796). 
This Nullah from its outlet to the Hooghly River to when it enters the Sunderbunds at the village of Tingeryah is in length 13 miles and six furlongs. The tides flow into it at both extremities but with greater force from the Hooghly, the effect of which double influx has a perpetual tendency of depositing the Mud with which the Waters of the Hoogly River in particular are so thickly impregnated, and it would appear by the Reports of the natives inhabiting its banks that since the first establishment of the Canal by Major Tolly the Soil has actually gathered in some parts to the depth of three or four feet...

a considerable portion of the Nullah probably the whole space that was originally dug to form the Communication is now whither dry at low water or retain so little water during the ebb as to be almost impassable for a Dingah...

To clear out the Canal in such a manner as to restore it to its former Condition and to render it an easy thoroughfare for Boats at all Seasons will be attended with a degree of Labor and Difficulty equal at least to what the original Projector had to encounter \& with an Expence [sic] little short perhaps of the sum he expended... ${ }^{65}$

To have an estimate of the amount to be expended to enhance the navigability of the canal, Colebrook suggested that four points should be considered. First, the canal needed to be protected at both ends to resist the immense pressure of water during the high tides, both from the river Hooghly and the Sunderbans; secondly, draining off the water from the bed of the canal; thirdly, closing up various creeks and channels which flowed into the canal; and finally, one needed to consider carefully the possibility of various springs which might be present in the bed of the canal, and which would pose difficulty in keeping the channel dry, or in a workable condition for the labourers. ${ }^{66}$ Following Colebrook's report, the government became hesitant to buy the canal in its present condition. The Board ordered Mrs. Tolly to keep the canal in a navigable condition as it was agreed upon in the original terms of the lease to Major Tolly. The government wanted to buy the canal as it was an important route for commerce with the provinces, and as it was not permissible for them to open any other channel in the vicinity as per the terms of the treaty with Tolly. It

\footnotetext{
${ }^{65}$ Ibid., Letter from the Surveyor General, Extract from Bengal Revenue Consultation (15 July 1796).
}

${ }^{66}$ Ibid. 
resolved to wait for some more time, review the state of the canal and then decide on the question of acquiring the canal. The Company finally took over the canal in 1805 after the expiration of the lease to Mrs. Tolly. It was believed to be a good source of revenue for the government at that point of time, as was evident from the collections of the preceding years. ${ }^{67}$

\section{CONCLUSION}

Debjani Bhattacharyya has alerted us to the necessity of writing the history of Calcutta keeping in mind the specificity of deltaic ecology. She argues that standard cartographic representations of Calcutta often miss the critical dimension of the mobile landscape on which it was built. For her, that landscape:

Stretches from the Sagar Islands, at the tip of Bay of Bengal, where the early mercantile ships of the monsoon traders from Europe were docked, along the shorelines that were solidified to connect it to Calcutta. This was a mobile space of sandbars, tidal sedimentations and seasonal movements of land that colonial officials fortified through infrastructures of the built environment. These fortifications happened both within the municipal city limits and outside. What linked them together was the way they worked to produce dried urban landscapes of economic value by the twentieth century. As land was dried, the tidal delta receded from our memories and the city became increasingly cut from its watery hinterland. ${ }^{68}$

Along with this reclamation of solid land from marsh and mud, water channels were also important for trade and communication. The specific topography in and around Calcutta made water an integral part of the urban system. By focusing on the making of one particular waterway, this article pays close attention to the interlocking issues of environment and economy-land, property, circulation, trade and commerce. These questions were linked to the broader concerns of sovereignty and the way the new government sought to manage the city and the province at large. The rights and privileges of landholders came in the way of the new speculator. The Company had the unenviable

\footnotetext{
${ }^{67}$ Bengal Despatches, E/4/659, 660-64, From London to the Revenue Department in Bengal, 1805-06, (21 Mar. 1806), OIOC, BL.

${ }^{68}$ Bhattacharyya, Empire and Ecology, 12.
} 
task of placating the grievances of the existing owners without completely alienating the individual entrepreneur and jeopardizing the project. These political and economic imperatives were inherent in Company governance in the early years after conquest. At a more general, subcontinental level, the fiscal and military needs of the Company were pulling it in two different ways during these tumultuous years of the late eighteenth century. The making of the canal illuminates how these impulses played out at the scale of the regional and the urban.

Through various infrastructural projects, the Company sought to modify, reorient, and erase existing patterns and claims to produce the space of the city. And in these endeavours, individual entrepreneurs played crucial role. Speculating on various projects of public works or establishing marketplaces became a lucrative opportunity for both Company men as well as free merchants. Negotiations around these projects brought forth important concerns of political economy for the Company. The maze of documents generated from the discussions between the individual proprietors and the Company helps us understand the ways through which the early colonial administrators sought to establish their hold over the people and spaces of an alien country. These initiatives brought forth issues of property and landholding, as well as conflicts with the customary rights of people. The decision-makers of the Company administration also faced difficulties defining and granting permission for these projects, as members were often not unanimous in their assessment of the situation.

In these early years after gaining effective political power in the province, the Company tried to establish its rule and power on the built environment of the fledgling town through various new regulations, negotiations, and erasure of previous norms. These issues animated the discussion in various other sectors of the early Company-rule. The idea was to fix, stabilise, and create a stable system of governance, both in terms of socioeconomic and politico-legal structures. These encounters give us a glimpse of the uncertain nature of the early Company-state. It had to negotiate a range of actors and institutions. Recent works on early colonial state-making in Bengal, especially those by Robert Travers and Jon Wilson, have reiterated the uncertain nature of the enterprise, where changing ideological concerns and local incomprehension forced Company officials to search for and negotiate with precolonial norms and practices. ${ }^{69}$ In reworking these systems, the Company eventually tried to erase the existing practices and establish

\footnotetext{
${ }^{69}$ Travers, Ideology and Empire; Jon E. Wilson, The Domination of Strangers.
} 
its hold, especially through defining property and landholding rights. But notions of past usages kept cropping up, frustrating the efforts of the Company.

In the case of Calcutta, Debjani Bhattacharyya has shown how the idea of property got reified with the transformation of the swampy landscape to solid landmass as part of an active state-making enterprise. ${ }^{70}$ This article has looked at the process of creating and stabilizing norms of governance in the early colonial city in spatial and commercial terms. It has tried to capture these issues through the study of one particular initiative that was crucial to navigating the watery terrain of the deltaic hinterland. And in this, the historicity of the social space framed the economic and political encounters of the early colonial government of the port-city.

\footnotetext{
${ }^{70}$ Bhattacharyya, Empire and Ecology.
} 